\title{
SEROPREVALENCE OF TOXOPLASMA GONDII AMONG COMMENSAL RODENTS FROM GIZA GOVERNORATE, EGYPT
}

\author{
By
}

MICHEAL WILLIAM MIKHAIL, AHMED HUSSIEN HASAN, KAMILLIA ALI ALLAM AND NEAMA MOSTAFA MOHAMMED

Research Institute of Medical Entomology, The General Organization for Institutes and Teaching Hospitals, Ministry of Health and Population, Dokki, Egypt.

( ${ }^{*}$ Correspondence: m.w.michy@hotmail.com)

\begin{abstract}
Toxoplasma gondii is an obligate intracellular zoonotic parasite that infects a large spectrum of warm-blood animals, including humans. Congenital toxoplasmosis is a worldwide problem. Rodents are intermediate hosts and serve as food for felids, the definitive hosts. A serological survey for antibodies to $T$. gondii was carried out among two species of commensal rodent species Rattus norvegicus and $R$. rattus, trapped from different localities within Abu-ElNomros center, Giza Governorate. Of 125 rats, $5(4.0 \%)$ had anti-Toxoplasma antibodies. Of 79 R. nor-vegicus $3(3.8 \%)$, and 46 R. rattus 2 (4.3\%). The results showed that mature and immature of males and females of both species had anti-toxoplasmal. This result was not statistically significant between two species of $R$. norvegicus and $R$. rattus and also between the two sexes of each species.
\end{abstract}

Key Words: Giza, Rural areas, Toxoplasmosis, Human risk, Rodents, R. norvegicus, $R$. rattus.

\section{Introduction}

Rodents are very common animals in many Egyptian Governorates (Rifaat et al, 1969, Shoukry et al, 1986; Morsy et al, 1988; Mikhail et al, 2010). Besides their economic hazard causing damage to agriculture and contamination of stored food materials, they also play an important role as reservoir host for many zoonotic diseases such as toxoplasmosis (Haridy et al, 2010), leishmaniasis (Morsy et al, 1982; El-Kady et $a l$, 1998), and trichinosis (Morsy et al, 2000), plaque and murine typhus (Abdon and Samaan, 1962; Butler, 2013, Stenseth, et $a l, 2008)$. They act as reservoir host for intestinal parasites such as hymenolepiasis, giardiasis, amoebiasis and schistosomiasis (Morsy et al, 1981; El-Nahal et al, 1982). Toxoplasma gondii is an increasing zoonosis of the worldwide distribution concern hazards in both human health and veterinary medicine. Although the final host is the cat, T. gondii infects all mammals including man (Edwards and Dubey, 2013) causing mild to fatal congenital complications (Saleh et al, 2016). The commonest sources of human infection are ingestion of tissue cysts in raw meat or of food or water contaminated with oocysts shed by felids and transplacental transmission (Pfaff et al, 2014). T. gondii has been shown to alter behavior of infected rodents in ways through to increase the rodent's chances of being preyed upon by cats (Berdoy et al, 2000). The live cycle of $T$. gondii can be broadly summarized into two components: a sexual component occurs only within cats and an asexual component that can occur within virtually all warm blooded animals. T. gondii is considered to have three stages of infection; the tachyzoite stage of rapid division, the bradyzoite stage of slow division within tissue cysts, and the oocyst environmental stage. When an oocysts or tissue cyst in ingested by a human or other warm-blooded animal, the resilient cyst wall is dissolved by proteolytic enzymes in the stomach and small intestine, freeing sporozoites from within the oocyst. The parasites differentiate into tachyzoites, the motile and quickly multiplying cellular stage of $T$. gondii tissue cysts in tissues such as brain and muscle tissue, form approximately 7-10 days after initial infection, (Robert and Darde, 2012). Infection often 
asymptomatic, immunocompetent individuals may present with fever, lymphadenopathy, muscle aches, and headache. Congenitally infected children may suffer impaired vision and mental retardation. Immunosuppressed patients may have central nervous system disease (encephalitis). The exposure to $T$. gondii is known risk factor for the development of schizophrenia, presumably through a direct pathological effect of the parasite on brain and behavior (Severance $e t$ al, 2012).

The present study investigated seropositivity for Toxoplasma gondii in commensal rodents Rattus norvegicus and Rattus rattus trapped from rural area, Abu-El-Nomros center, Giza Governorate, Egypt.

\section{Materials and Methods}

Wire box traps were deodorized by cleaning with hot water and soap before used. Traps were baited, distributed in selected houses at sunset at Abu-El-Nomros center,
Giza Governorate, Egypt. Traps collected next morning and transported to the laboratory (WHO, 1970). In laboratory they were caged individually and each animal was identified to species and them given water and a suitable diet. The studies were done from October 2015 to July 2016. Animals were anaesthetized with diethyl ether and blood sample will be collected from heart and centrifuged for serum. Of 125 serum samples will be tested for the anti-Toxoplasma IgG antibodies, by using commercially available enzyme-linked immuno-sorbent assay (ELISA). The levels of antibody were determined by reading the optical density (O.D.) at $450 \mathrm{~nm}$ by ELISA reader. The ratio between the O.D. value of the sample and the Cut-off were calculated. Data subjected to analysis for variance and the method of least significant differences (L.S.D.), the method of Duncan (1955) was used.

\section{Results}

The results are shown in tables (1, 2 and 3$)$.

Table1: T. gondii among rodent species collected from Abu-El-nomros center, Giza Governorate.

\begin{tabular}{|c|c|c|c|c|c|c|c|c|c|c|}
\hline \multirow[b]{2}{*}{ Rattus } & \multirow[t]{2}{*}{ Sex } & \multirow{2}{*}{$\begin{array}{l}\text { No tested } \\
\text { Rats }\end{array}$} & \multicolumn{2}{|c|}{ Weight of rats } & \multicolumn{3}{|c|}{ Mature rats } & \multicolumn{3}{|c|}{ Immature rats } \\
\hline & & & Range & Mean & rats & -ve IgG & + ve IgG & rats & -ve IgG & + ve IgG \\
\hline \multirow{3}{*}{ norvegicus } & Males & 46 & $84-512$ & 289 & 44 & 43 & 1 & 2 & 1 & 1 \\
\hline & Females & 33 & $76-454$ & 276 & 30 & 29 & 1 & 3 & 3 & 0 \\
\hline & Total & 79 & - & - & 74 & 72 & 2 & 5 & 4 & 1 \\
\hline \multirow[t]{3}{*}{ rattus } & Males & 23 & $40-187$ & 112 & 15 & 14 & 1 & 8 & 8 & 0 \\
\hline & Females & 23 & $40-160$ & 101 & 16 & 16 & 0 & 7 & 6 & 1 \\
\hline & Total & 46 & - & - & 31 & 30 & 1 & 15 & 14 & 1 \\
\hline
\end{tabular}

Table 2: Correlation between $R$. norvegicus and $R$. rattus infected with Toxoplasma gondii

\begin{tabular}{|c|c|c|c|l|}
\hline Species & No. & Mean & SD & \multicolumn{1}{|c|}{ Levene's Test } \\
\hline R. norvegicus & $\mathrm{n}=79$ & 0.03787 & 0.19236 & $\mathrm{~F}=0.090$ \\
\cline { 1 - 4 } R rattus & $\mathrm{n}=46$ & 0.04348 & 0.20618 & $\mathrm{P}>0.05$ \\
\hline
\end{tabular}

Table 3: Correlation between males and females of $R$ norvegicus and $R$. rattus infected with Toxoplasma gondii.

\begin{tabular}{|c|c|c|c|c|}
\hline Rattus & Sex & Mean & SD & Levene's Test \\
\hline \multirow[t]{2}{*}{ norvegicus } & $\widehat{\partial}(n=46)$ & 0.04348 & 0.174 & \multirow{2}{*}{$\begin{array}{l}F=0.360 \\
P>0.05\end{array}$} \\
\hline & $q(n=33)$ & 0.03030 & 0.206 & \\
\hline \multirow{2}{*}{ rattus } & $\delta(n=23)$ & 0.04348 & 0.209 & \multirow[t]{2}{*}{$\mathrm{F}=0.00$} \\
\hline & ㅇ $(\mathrm{n}=23)$ & 0.04348 & 0.209 & \\
\hline
\end{tabular}

\section{Discussion}

In the present study, $R$. norvegicus and $R$. rsttus from Abu-El-Nomros center showed anti-toxoplasmal antibodies $3(3.8 \%)$ and 2 (4.3\%). Of 46 males $R$. norvegicus 2 (4.3\%) and of 33 female rats $1(3 \%)$ were seropositive. Of 23 male and female $R$. rattus one (4.3\%) was seropositive. This result showed no significant between $R$. norvegicus and $R$. rattus $(\mathrm{F}=0.090 \& \mathrm{P}>0.05)$ and between sexes of both species $(\mathrm{F}=0.360 \& \mathrm{P}>0.05$ for $R$. norvegicus and $\mathrm{F}=0.00$ for $R$. rattus). ElShazly et al. (1991) in Dakahlia Egypt examined four species of commensal rodents ( $R$. norvegicus, $R$. rattus, Mus musculus and Acomys cahirinus) trapped from different 
localities and reported that $R$. norvegicus, 32/200 (16\%), R. rattus, 29/228 (12.7\%) M. musculus, 2.87 (2.3\%) and A. cahirinus, 5/69 (7.2\%) were IHA-positive.

Abroad, Asai et al. (1988) in Japan reported IHA-seropositivity in $27(11.5 \%)$ R. norvegicus. Dubey et al. (2006) in Grenada, west India reported positivity in $238 R$. norvegicus, which tissue samples of hearts and brains were microscopically examined and were $2(0.8 \%)$ of 238 were seropositive. Yin et al. (2010) in southern China reported $T$. gondii in female $R$. norvegicus and $R$. flavipectus, seropositivity was $(3.4 \% \& 3.0 \%)$ respectively.

Dabritz et al. (2008) in Morro Bay (California among 523 wild rodents reported seropositivity in $17 \%$ (88/523), which were 26\% (85/328) Peromyscus sp. and 8\% (3/37) Spermophillus beecheyi. Fourteen percent (23/161) of rodents and 15\% (16/109) of rodents from sites adjacent to riparian habitats had antibodies to $T$. gondii, compared to $19 \%(49 / 253)$ of rodents captured in habitats not associated with water, this difference was not significant.

Jittapalapong et al. (2011) showed that overall 21 of $461(4.6 \%)$ rodents had diagnostic significant to $T$. gondii during rodents captured from either forested or anthropized areas in Thailand. Vujanic et al. (2011) reported that Toxoplasma gondii infection was examined in $144 \mathrm{R}$. norvegicus and $12 \mathrm{M}$. musculus captured in three locations in Belgrade city characterized by poor housing and degraded environment. In rats, specific IgG antibodies were detected by modified agglutination test in $22(27.5 \%)$ of the 80 blood samples available.

Ahmad et al. (2012) in Pakistan found seropositive $T$. gondii $(58.57 \%)$ in $R$. rattus followed by $M$. musculus (36.66\%) and lowest was in man (11.33\%). Costa et al. (2012) in Brazil reported antibodies to $T$. gondii in 13 (38.2\%) of $R$. rattus in Femandode Noronha which is an archipelago of 21 Islands and islets in Atlantic Ocean, State of Pemambuco,. Mosallanejad et al. (2012) report- ed that wild rats were infected with $T$. gondii due to ingestion of food or water contaminated with oocysts with an important role in zoonotic $T$. gondii transmission. Rats captured among Ahvaz district, southern Iran indicated that thirty-one of the 127 serum samples $(24.41 \%)$ had antibodies against $T$. gondii, prevalence was higher in females (24.66\%) than males $(24.07 \%)$.

Fournier et al. (2013) reported a zoonotic T. gondii among wild of vertebrates. Siqueira et al. (2013) in Brazil found antibodies Toxoplasma gondii in 6.7\% (15/223) of marsupials and $5,7 \%(10 / 174)$ of rodents, without association between positivity in marsupias and/or rodents and sex, age, or areas of collection in the Atlantic Forest. RendonFranco et al. (2014) in Mexico reported T. gondii transmission between rodents and members of felids and found an important role of rodents in the sylvatic cycle of $T$. gondii prevalence 7\% (3/44) and 33\% (4/12) in Sigmodon hispidus and Liomys irroratus, respectively.

Gennari et al. (2015) in southeastern Brazil reported seropositivity in 151 rodents and 48 marsupils in the Atlantic Forest, Sao Paulo State. The anti- $T$. gondii antibodies were in $8.6 \%(13 / 151)$ of rodents and $10.4 \%$ (5/48) of marsupials. Normaznah et al. (2015) in Malaysia showed that $T$. gondii antibodies were $5.9 \%(31 / 526)$ of rodents from various locations, but were commonest in commensal, $R$. exulans $(9 / 64,14.0 \%), R$. argentiventer $(2 / 8,25 \%), R$. rattus diardii $(10 / 166$, $6.0 \%)$, and $R$. tiomanicus $(6 / 215,2.7 \%)$. Of forest rodents positivity was in Maxomys rajah $(1 / 9,11.1 \%)$ and $R$. bowersi $(1 / 12$, 8.3\%). Gotteland et al. (2014) reported that toxoplasmosis infected rodents was prevalent in rural areas but its spatial distribution was poorly known. In particular, it is unclear if areas of high density of cats, the only hosts excreting $T$. gondii, constitute foci of high prevalence. Commensal rats were more infected to $T$. gondii than non-commensal species. However, the major determinant of the risk of infection was the distance to the 
nearest farm, which explained the risk in all species or non-commensal species only.

Generally speaking, there are seven means of acquiring toxoplasmosis in humans (Tenter et al, 2000): 1- Through vertical transmission from an infected mother to her fetus congenital infection (Congenital). 2- Ingestion of infectious oocysts from the environment (usually from soil contaminated with feline feces), 3- Cleaning cat litter boxes. 4Drinking unpasteurized goat milk or equine milk. 5- Ingestion of tissue cysts in meat from an infected animal, 6-Eating unwashed raw vegetables or fruits. 7- Via blood transfusion or organ transplantation from an infected donor, (Acquired infection). 8- Also, accidentally by needle-stick injuries as well as handling specimens that may contain viable organisms to the laboratory for examination (Herwaldt, 2001).

On the other hand, the endemicity of zoonotic toxoplasmosis was reported not only in Egypt (Shaapan, 2016), but also in many countries Worldwide as Jordan (Morsy and Michael, 1980), Libya (Kassem and Morsy, 1991), Saudi Arabia (Alanazi, 2013), Turkey (Yağc1 Yücel et al, 2014), Kuwait (El-Azazy et al, 2015), Yemen (Mahdy et al, 2017), Italy (Formenti et al, 2017). Harfoush and Tahoon (2010) in rodents infested Egyptian farm, Toxoplasma-IHAT was detected in locally bred domestic ducks, free-range chickens, turkey and domestic rabbits. Besides, Elsheikha et al. (2009) reported that T. gondii infection had a prominent influence on the association between oxidative stress biomarkers and immune-suppression status in seropositive blood donors as well as cerebral toxoplasmosis was reported (Prandota et al, 2014)

\section{Conclusion}

Generally speaking, toxoplasmosis is real public health zoonotic parasite of wide geographical and zoological distribution.

The outcome results showed that Giza Governorate was featured by the presence of high population density of rats and mice. Serological survey for $T$. gondii in the com- mensal rodents, $R$. norvegicus and Rattus rattus proved high positivity. Therefore, the intimate association of rodents with human plays potential danger as disseminators as serious pathogens problems. This must be taken into consideration from the medical and veterinary point of view.

\section{References}

Abdon, AH, Samaan, M, 1962: Egyptian rodents and their public health importance. J. Arab. Vet. Med. Assoc. 22, 4:403-31.

Ahmad, S, Maqbool, A, Mahmood-Ui-Hassan, M, Mushtaq-Ul-Hassan, M, Anjum, AA, 2012: Prevalence of Toxoplasma gondii antibodies in human beings and commensal rodents trapped from Lahore, Pakistan. J. Anim. Plant Sci. 22, 1:51-53.

Alanazi, AD, 2013: Determination of seropositivity for Toxoplasma gondii in sheep, goats and camels slaughtered for food and human consumptions in Riyadh municipal abattoirs, Saudi Arabia. J. Egypt. Soc. Parasitol. 43, 3:569-76.

Asai, T, Kinjo,T, Minamoto, N, Sugiyama, M. 1988: Isolation and serological survey of several infectious disease agents in wild rats (Japanese). Res. Bull. Fac. Agric. Gifa University 53:36373.

Berdoy, M, Webster, J, Macdonald, D, 2000: fatal attraction in rats infected with Toxoplasma gondii. Proceed. Roy. Soc. Biol. Sci. 267, 1452: 1591-94.

Butler, T, 2013: Plague gives surprises in the first decade of the $21^{\text {st }}$ Century in the United States and worldwide. Amer. J. Trop. Med. Hyg. 894:788-93.

Costa, DGC, Marvulo, MFV, Sira, JSA, Santana, SC, Magalhaens, FJR, et al, 2012: Seroprevalence of toxoplasma gondii in domestic and wild animals from the Femabode Noronha, Brazil. J. Parasitol. 98, 3:679-80.

Dabritz, HA, Miller, MA, Gardner, IA, Packham, AE, Atwill, ER, et al, 2008: Risk factors for Toxoplasma gondii infection in wild rodents from central Coastal (California) and a review of T. gondii prevalence in rodents. J. Parasitol. 94, 3:675-83.

Dubey, JP, Bhaiyat, MI, Macpherson, CNL, Allie, C, Chikweto, A, et al, 2006: Prevalence of toxoplasma of Toxoplasma gondii in rats (Rattus norvegicus) in Grenada, West Indies. J. Parasitol. 92, 5:1107-8. 
Duncan, TMW, 1955: Multiplerange and multiple F-tests. Biomertics. 11:1-42.

El-Kady, GA, Makled, KM, Morsy, TA, Morsy, ZS, 1998: Rodents, their seasonal activity, ecto-and blood parasites in Saint Catherine area, South Sinai Governorate, Egypt. J. Egypt. Soc. Parasitol. 28, 3:815-25.

Elsheikha, HM, El-Motayam, MH, AbouelNour, MF, Morsy, AT, 2009: Oxidative stress and immune-suppression in Toxoplasma gondii positive blood donors: implications for safe blood transfusion. J. Egypt. Soc. Parasitol. 39, 2: 421-8.

Edwards, JF, Dubey, JP, 2013: Toxoplasma gondii abortion storm in sheep on a Texas farm and isolation of mouse virulent atypical genotype $T$. gondii from an aborted lamb from a chronically infected ewe. Vet. Parasitol. 192, 1/3: 129-36.

El-Azazy, OM, Abdou, NE, Khalil, AI, Al-Batel, MK, Majeed, QA, et al, 2015: Potential zoonotic trematodes recovered in stray cats from Kuwait Municipality, Kuwait. Korean J. Parasitol. 53, 3:279-87

El Nahal, HS, Morsy, TA, Bassili, WR, El Missiry, AG, Saleh, MSM, 1982: Antibodies against 3 parasites of medical importance in Rattus sp. collected in Giza Governorate, Egypt. J. Egypt. Soc. Parasitol. 12, 2:287-93.

El-Shazly, AM, Romia, SA, Ganayni, A, Abou-Zakham, AA, Morsy, TA. 1991: Antibodies against some zoonotic parasites in commensal rodents trapped from Dakahlia Governorate, Egypt. J. Egypt. Soc. Parasitol. 21, 1: 169-77.

Formenti, N, Gaffuri, A, Trogu, T, Viganò, R, Ferrari, N, et al, 2016: Spread and genotype of Toxoplasma gondii in naturally infected alpine chamois (Rupicapra r. rupicapra). Parasitol. Res. 115, 5:2115-20.

Fournier, GF, Silva, JIG, Cabral, AD, Pena, HF, Gennari, SM. 2013: Toxoplasma gondii in domestic and wild animals from forest fragments of the municipality of Natal, northeastern Brazil. Brazilian J. Vet. Res. Anim. Sci. 50, 5:353-58.

Gennari, SM, Ogrzewaiska, MH, Soares, HS, Saraiva, DG, Pinter, A, et al, 2015: Toxoplasma gondii antibodies in wild and marsupials from the Atlantic Forest, State of Sao Paulo, Brazil. Brazil. J. Vet. Parasitol.24, 3: 379-82.

Gotteland, C, Chaval, Y, Villena, I, Galan, M, Geers, R, et al, 2014: Species or local environment, what determines the infection of rodents by Toxoplasma gondii? Parasitol.141, 2:259-68.
Harfoush, M, Tahoon, Ael-N, 2010: Seroprevalence of Toxoplasma gondii antibodies in domestic ducks, free-range chickens, turkeys and rabbits in Kafr El-Sheikh Governorate Egypt. J. Egypt. Soc Parasitol. 40, 2:295-302.

Haridy, FM, Saleh, NMK, Khalil, HHM, Morsy, TA, 2010: Anti-Toxoplasma gondii antibodies in working donkeys and donkey's milk in Greater Cairo, Egypt. J. Egypt. Soc. Parasitol. 40, 2:459-64.

Herwaldt, BL, 2001: Laboratory-acquired parasitic infections from accidental exposures. Clin. Microbiol. Rev. 14:659-88.

Jittapalapong, S, Sarataphan, N, Maruyama, S, Hugot, JP, Morand, S, et al, 2011: Toxoplamosis in rodents: Ecological survey and first evidences in Thailand. Vector Bor. Zoon. Dis. 11, 3:231-37.

Kassem, HH, Morsy, TA, 1991: The prevalence of anti-Toxoplasma antibodies among pregnant woman in Benghazi (S.P.L.A.J.), Libya. J. Egypt. Soc. Parasitol. 21, 1:69-74.

Mahdy, MA, Alareqi, LM, Abdul-Ghani, R, Al-Eryani, SM, Al-Mikhlafy, AA, et al, 2017: A community-based survey of Toxoplasma gondii infection among pregnant women in rural areas of Taiz governorate, Yemen: the risk of waterborne transmission. Infect. Dis. Poverty. 6, 1: 26-32.

Mihkail, MW, Soliman, MI, YM, 2010: Infestion rate of tick, mite and lice among rodent species in Menoufia Governorate, Egypt. J. Egypt. Soc. Parasitol. 40, 2:425-37.

Mosallanejad, B, Avizeh, R, Jalali, MHR, Hamididinejat, H. 2012: Seroprevalence of Toxoplasma gondii among wild rats (Rattus rattus) in Ahvaz district, southwestern Iran. Jundishapur J. Microbiol.5, 1:332-35.

Morsy, TA, Michael, SA, 1980: Toxoplasmosis in Jordan. J. Egypt. Soc. Parasitol. 10, 2:457-70.

Morsy, TA, Micheal, SA, Abou El Seoud, SF, 1981: Leishmaniasis in rodents caught in Suez Canal Zone, Egypt. J. Egypt. Soc. Parasitol. 11: 241-52.

Morsy, TA, Michael, SA, Bassili, WR, Salah, MSM, 1982: Studies of rodents and their zoonotic parasites, particularly Leishmania, in Ismailia Governorate, Egypt .J. Egypt. Soc. Parasitol. 12, 2:565-85.

Morsy, TA, Abu El-Ela, R, El-Gozamy, MR, 1988: The commensal rodents and their flea fauna in Alexandria City, Egypt. J. Egypt. Soc. Parasitol. 18, 1:11-26. 
Morsy, TA, Ibrahim, BB, Haridy, FM, Rifaat, MA, 2000: Trichinella encysted larvae in slaughtered pigs in Cairo (1995-1999). J. Egypt. Soc. Parasitol. 30, 3:753-60.

Normaznah, Y, Noor-Azizah, MA, Azuan, M I, Latifah, I, Rahmat, S, et al, 2015: Seroprevalence of Toxoplasma gondii in rodents from various locations in Peninsular Malaysia. Southeast Asian J. Trop. Med. Pub. Hlth.46, 3:388-95.

Owen, MR, Trees, AJ, 1999: Genotyping of Toxoplasma gondii associated with abortion in sheep. J. Parasitol., 85:382-4.

Pfaff, AW, de-la-Torre, A, Rochet, E, Brunet, J, Sabou, M, et al, 2014: New clinical and experimental insights into Old World and Neotropical ocular toxoplasmosis. Int. J. Parasitol. 44, 2 : 99-107.

Prandota J, Gryglas, A, Fuglewicz, A, Zeslawska, A, Ujma-Czapska, B, et al, 2014: Recurrent headaches may be caused by cerebral toxoplasmosis. World J. Clin. Pediatr. 3, 3:59-68.

Rendon-Franco, E, Xicotencatl-Garcia, L, Rico-Torres, CP, Munoz-Garciu, CI, et al, 2014: Toxoplasmosis seroprevalence in wild small rodents, potentially preys of ocelots in north-eastern Mexico. Parasit. 21:57-61.

Rifaat, MN, Mohammed, AM, Shawarby, A A, Arafa, MS, 1969: Incidence and distribution of domestic and commensal rodents in U.A.R. J. Egypt. Pub. Hlth. Assoc. 44, 2: 127-46.

Robet, GF, Darde, ML, 2012: Epidemiology of and diagnostic strategies for toxoplasmosis: Reviews. Clin. Microbiol. 25, 2: 264-96.

Saleh, AMA, Al-Agroudi, MA, Morsy, TA, 2016: Occupational, nosocomial or hospital acquired toxoplasmosis. J. Egypt. Soc. Parasitol. 46, 3:407-18.

Severance, EG, Kannan, G, Gressitt, KL, Xiao, JC, Alaedini, A, et al, 2012: Anti-gluten immune response following Toxoplasma gondii infection in mice. PLOS ONE.7.11:e50991.

Shaapan, RM, 2016: The common zoonotic protozoal diseases causing abortion. J. Parasit. Dis. 40, 4:1116-29. Review.

Shoukry, A, Morsy, TA, Abu-Hashish, IA, ElKady, GA, 1986: The seasonal activities of two commensal rats and flea index in North Sinai, Egypt. J. Egypt. Soc. Parasitol. 16:385-93.

Siqueira, DB, Alessio, FM, Mauffrey, JF, Marvulo, MFV, Ribeiro, VO, et al, 2013: Seroprevalence of Toxoplasma gondii in wild marsupials and rodents from the Atlantic forest of Pernambuco State, Northeastern Region, Brazil. J. Parasitol, 99, 6:1140-43.

Stenseth, NC, Atshabar, BB, Begon, BB, Belmain, SR, Bertherat, E, et al, 2008: Plague: past, present and future. PLos. Med. 5:e3

Tenter, A, Heckeroth, A, Weiss, L, 2000: Toxoplasma gondii from animals to humans. Int. J. Parasitol. 30:1217-58.

Vujanic M, Ivovic, V, Kataranovski, M, Nikolic, A, Bobic, B, et al, 2011: Toxoplasmosis in naturally infected rodents in Belgrade, Serbia. Vector Bor. Zoon. Dis. 11, 8:1209-11.

WHO, 1970: Instructions of determining the susceptibility or resistance of rodents to anticoagulant rodenticides. Insecticide resistance and vector control. Tech. Rep. Ser. WHO. 443:140-7.

Yağcı Yücel, S, Yaman, M, Kurt, C, Babür, C, Celebi, B, et al, 2014: Seroprevalance of brucellosis, listeriosis and toxoplasmosis in cattle in Adana province of Turkey. Turkiye Parazitol. Derg. 38, 2:91-6.

Yin, Chuang-Cheng, He, Yong, Zhou, DongHui, Yan, Chao, He, Xian-Hui, W, et al, 2010: Seroprevalence of Toxoplasma gondii in Rats in southern China. J. Parasitol.96, 6:1233-4 